\title{
PENJAJAKAN PENERAPAN SISTEM MANAJEMEN PENGETAHUAN DI SEKOLAH MENENGAH KEJURUAN
}

\author{
Jap Tji Beng ${ }^{1,5}$, Fenny Lusiana ${ }^{2,5}$, Kirey Larasati ${ }^{3,5}$, Sri Tiatri ${ }^{4,5^{*}}$ \\ ${ }^{1}$ Fakultas Teknologi Informasi, Universitas Tarumanagara, Jakarta \\ Email:t.jap@untar.ac.id \\ ${ }^{2}$ Fakultas Teknologi Informasi, Universitas Tarumanagara, Jakarta \\ Email:fenny.825160026@stu.untar.ac.id \\ ${ }^{3}$ Fakultas Teknologi Informasi, Universitas Tarumanagara, Jakarta \\ Email: kirey.535160088@stu.untar.ac.id \\ ${ }^{4}$ Fakultas Psikologi, Universitas Tarumanagara, Jakarta \\ *) Corresponding Author Email: sri.tiatri@untar.ac.id \\ ${ }^{5}$ Science, Technology, and Society Research Group, Universitas Tarumanagara, Jakarta
}

Masuk : 08-12-2020, revisi: 30-04-2021, diterima untuk diterbitkan : 30-04-2021

\begin{abstract}
Knowledge Management System (KMS) is a learning solution that is known to be effective in various educational contexts in the era of information and communication technology. One educational context that is expected to benefit from is Vocational High Schools (SMK). In this education, the most learned things are skills. It is not yet known, what kind of Knowledge Management System suits the learning needs of students in SMK. This study aims to explore the needs of vocational students associated with the application of the Knowledge Management System. Research participants are 1.600 vocational students in 5 cities of Indonesia (83 students from Pontianak, 304 students from Manado, 177 students from Belitung, 238 students from Yogyakarta, and 798 students from Salatiga) Data collection was carried out through surveys and interviews. The results showed that $100 \%$ of students stated that KMS was needed in their learning system. Most students 63\% (996 students) need a KMS that includes all knowledge, both related and unrelated to their field of expertise. The results of this research can be valuable information for the development of KMS in SMK in Indonesia.
\end{abstract}

Keywords: Knowledge Management System, Vocational School, students, Indonesia

\begin{abstract}
ABSTRAK
Sistem Manajemen Pengetahuan atau Knowledge Management System (KMS) adalah salah satu solusi belajar yang diketahui efektif diterapkan dalam berbagai konteks pendidikan di era teknologi informasi dan komunikasi. Salah satu konteks pendidikan yang diperkirakan akan mendapatkan manfaat adalah Sekolah Menengah Kejuruan (SMK). Dalam pendidikan ini, hal yang paling banyak dipelajari adalah keterampilan. Belum diketahui Sistem Manajemen Pengetahuan seperti apa yang sesuai dengan kebutuhan pembelajaran para siswa di SMK. Penelitian ini bertujuan menjajaki kebutuhan siswa SMK yang terkait dengan penerapan Sistem Manajemen Pengetahuan. Partisipan penelitian adalah 1.600 siswa SMK di 5 kota Indonesia (83 Siswa Pontianak, 304 Siswa Manado, 177 Siswa Belitung, 238 Siswa Yogyakarta, dan 798 Siswa Salatiga). Pengambilan data dilaksanakan melalui survei dan wawancara. Hasil penelitian menunjukkan bahwa 100\% siswa menyatakan bahwa KMS diperlukan dalam sistem pembelajaran mereka. Sebagian besar siswa 63\% (996 Siswa) memerlukan KMS yang mencakup seluruh pengetahuan, baik yang terkait maupun yang tidak terkait dengan bidang keahlian mereka. Hasil penelitian ini dapat menjadi informasi yang berharga bagi pengembangan KMS di SMK di Indonesia.
\end{abstract}

Kata Kunci: Knowledge Management System, Sekolah Menengah Kejuruan, siswa, Indonesia

\section{PENDAHULUAN}

\section{Latar Belakang}

Dalam era Revolusi Industri 4.0, diperlukan keterampilan bekerja, termasuk di dalamnya keterampilan dalam hal teknologi informasi dan komunikasi. Secara umum, keterampilan dalam teknologi informasi dan komunikasi ini dapat mempengaruhi dan mendorong pertumbuhan ekonomi yang luas. Salah satu program pendidikan yang dapat memanfaatkan keterampilan dalam teknologi informasi dan komunikasi adalah Sekolah Menengah Kejuruan (SMK). Dalam program pendidikan ini, cukup banyak keterampilan yang perlu dikuasai, yang dapat memanfaatkan, 
maupun mengembangkan teknologi informasi yang terkait.

Sekolah Menengah Kejuruan (SMK) adalah salah satu bentuk satuan pendidikan formal. Satuan pendidikan ini menyelenggarakan pendidikan kejuruan, pada jenjang pendidikan menengah lanjutan, sebagai lanjutan pendidikan menengah pertama, misalnya SMP/MTs atau bentuk lain yang sederajat (Pusat Data dan Informasi Pendidikan Balitbang - Depdiknas, 2004). SMK memiliki kurikulum yang diharapkan dapat mempersiapkan siswa untuk pasar tenaga kerja yang lebih baik, mengembangkan kompetensi siswa, dan meningkatkan motivasi siswa (Misbah et al, 2020).

Di China pada tahun 2018, jumlah peserta didik SMK meliputi 39.47\% sampai 41.37\% dari jumlah peserta didik Sekolah Menengah Lanjutan di negara tersebut (Ministry of Education The People's Republic of China, 2019). Di Indonesia, jumlah SMK adalah 14,301 SMK dengan berbagai jurusan (Badan Pusat Statistik, 2019). SMK di Indonesia meliputi 3,622 SMK Negeri dan 10,679 SMK Swasta. 220 SMK berlokasi di DIY Yogyakarta (1.5\%), 223 SMK di Kalimantan Barat (1.5\%), dan 58 SMK di Kepulauan Bangka Belitung (0.4\%). SMK terbanyak berada di Jawa Barat yaitu sebanyak 2,943 SMK (20.7\%). Saat ini, terdapat 5,249,149 siswa SMK. Di Yogyakarta terdapat 90,390 siswa (1.8\%), di Pontianak 75,603 siswa (1.4\%), dan di Belitung 25,883 siswa $(0.5 \%)$. Beberapa jurusan favorit di antaranya adalah teknik dan teknologi, teknologi informasi dan komunikasi, bisnis dan manajemen, serta pariwisata.

Dalam proses pendidikan, salah satu alat yang dapat digunakan untuk mencapai keterampilan adalah KMS (Knowledge Management System). Sistem Manajemen Pengetahuan yang selanjutnya dalam tulisan ini akan disebut sebagai Knowledge Management System (KMS) menerapkan konsep klasik dari Nonaka (1994). Konsep KMS ini menggambarkan proses interaksi yang berkesinambungan dari pengetahuan tacit dan pengetahuan eksplisit dalam penciptaan pengetahuan organisasi (Nonaka et al., 2000). Nonaka (1994) berargumen bahwa ketika pengetahuan dibangun oleh individu, maka organisasi berperan penting dalam mengartikulasikan pengetahuan tersebut.

Pada awal abad ke-21, manajemen pengetahuan difokuskan terutama pada pengendalian kinerja, mengelola motivasi, dan tindakan seseorang. Selanjutnya manajemen pengetahuan semakin berkembang ke konsep pembelajaran organisasi (Daňa et al., 2018). External Knowledge seperti yang sebagian dikandung dalam KMS dapat menjadi kerangka teoritis dalam melakukan analisis, dan sebagai bagian penting dari penciptaan pengetahuan. Kerangka teoritis ini dapat diaplikasikan untuk memfasilitasi penciptaan dinamika pengetahuan untuk individu dan organisasi (Wang et al., 2016).

Hasil penelitian beberapa institusi pendidikan di dunia menunjukkan bahwa KMS sudah dikembangkan dan digunakan di beberapa negara, seperti Hong Kong (Chu et al., 2011), pada pendidikan tinggi di Afrika, Australia, United Kingdom, dan India (Ramjeawon \& Rowley, 2017). KMS juga digunakan pada berbagai tingkat pendidikan, seperti perguruan tinggi (misalnya Natek \& Zwilling, 2014; Ramjeawon \& Rowley, 2017); dan sekolah menengah (misalnya, Chu et al., 2011). KMS dapat digunakan sebagai strategi alternatif oleh sekolah untuk memberi guru dengan keterampilan yang relevan, dalam menghadapi tantangan, untuk meningkatkan kinerja. 
Hasil penelitian Harb dan Abu-Shanab (2020), menunjukkan bahwa implementasi KMS pada pendidikan tinggi ataupun universitas memiliki frekuensi paling tinggi. Hal ini menunjukkan bahwa KMS dibutuhkan dan dianggap penting untuk pengembangan inovasi di dalam dunia pendidikan.

Knowledge Management System (KMS) adalah salah satu solusi belajar yang diketahui efektif diterapkan dalam berbagai konteks pendidikan di era teknologi informasi dan komunikasi. Salah satu konteks pendidikan yang diperkirakan akan mendapatkan manfaat adalah Sekolah Menengah Kejuruan (SMK). Dalam pendidikan ini, hal yang paling banyak dipelajari adalah keterampilan (Kemendikbud, Undang-Undang Sistem Pendidikan Nasional Nomor 20 tahun 2003). Namun demikian, belum diketahui KMS seperti apa yang sesuai dengan kebutuhan pembelajaran para siswa di SMK. Penelitian ini bertujuan menjajaki kebutuhan siswa SMK yang terkait dengan penerapan KMS.

\section{Rumusan Masalah}

Berdasarkan uraian di atas, permasalahan yang berusaha dijawab dalam penelitian ini adalah, apakah Knowledge Management System (KMS) dipandang perlu oleh siswa SMK? Selain itu, KMS seperti apakah yang sesuai dengan kebutuhan siswa SMK?

\section{METODE PENELITIAN}

Partisipan penelitian ini adalah 1.600 Siswa SMK dari 5 Kota di Indonesia. Partisipan terdiri dari 306 siswa laki- laki dan 1.294 siswa perempuan. Gambaran partisipan dapat dilihat pada tabel 1 di bawah ini.

Tabel 1.

Gambaran Partisipan Berdasarkan Jenis Kelamin dan Usia

\begin{tabular}{ccccc}
\hline No. & Kota & Laki-Laki & Perempuan & Usia Rata-Rata (tahun) \\
\hline 1. & Tanjungpandan & 70 & 107 & 15 \\
2. & Pontianak & 37 & 46 & 15 \\
3. & Manado & 152 & 152 & 15 \\
4. & Yogyakarta & 22 & 216 & 16 \\
5. & Salatiga & 25 & 773 & $>16$ \\
\hline
\end{tabular}

Ditinjau dari jurusan, maka partisipan penelitian ini terbanyak adalah di jurusan tata boga/ restoran (292 orang, 18.25\%), sementara paling sedikit adalah di jurusan rekayasa perangkat lunak (34 orang, $2.13 \%$ ). Tabel 2 menunjukkan gambaran partisipan ditinjau dari jurusan. 
Tabel 2.

Gambaran Jurusan Partisipan Penelitian

\begin{tabular}{llll}
\hline No. & Jurusan & Jumlah & Presentase (\%) \\
\hline 1. & Akuntansi & 288 & 18.00 \\
2. & Administrasi Perkantoran & 229 & 14.31 \\
3. & Pemasaran & 199 & 12.44 \\
4. & Tata Boga/ Restoran & 292 & 18.25 \\
5. & Tata Kecantikan & 121 & 7.56 \\
6. & Tata Busana & 112 & 7.00 \\
7. & Multimedia & 43 & 2.69 \\
8. & Pariwisata & 91 & 5.69 \\
9. & Perhotelan & 191 & 11.94 \\
10. & Rekayasa Perangkat Lunak & 34 & 2.13 \\
\hline
\end{tabular}

Ditinjau dari alasan sekolah di SMK, maka alasan utama partisipan adalah dapat segera bekerja setelah lulus dari SMK (670 orang, 41.05\%), sedangkan alasan paling sedikit adalah jarak SMK yang dekat dari rumah (16 orang, 1.0\%). Tabel 3 menunjukkan gambaran partisipan berdasarkan alasan sekolah di SMK.

Tabel 3.

Gambaran Alasan Bersekolah di SMK

\begin{tabular}{llll}
\hline No. & Alasan & Jumlah & Presentase (\%) \\
\hline 1. & Dapat segera bekerja & 670 & 41.05 \\
2. & Motif pribadi lain yang tidak dapat dikategorisasikan & 298 & 18.26 \\
3. & Dapat bekerja dan kuliah & 174 & 10.88 \\
4. $\quad \begin{array}{l}\text { SMK yang dipilih merupakan sekolah atau jurusan terbaik di } \\
\text { daerah tersebut }\end{array}$ & 118 & 7.38 \\
& Minat dan ingin memperdalam ilmu, sesuai kemampuan & 171 & 10.69 \\
5. & Mudah mencari pekerjaan dan ada pengalaman PKL & 153 & 9.56 \\
7. & Dekat dari rumah & 16 & 1.0 \\
\hline
\end{tabular}




\section{HASIL DAN PEMBAHASAN}

Berdasarkan data yang telah diolah, maka ditemukan bahwa $100 \%$ siswa menyatakan bahwa Knowledge Management System (KMS) diperlukan dalam sistem pembelajaran mereka. Sebagian besar siswa 63\% (996 siswa) memerlukan KMS yang mencakup seluruh pengetahuan, baik yang terkait maupun yang tidak terkait dengan bidang keahlian mereka. Selain itu, penelitian ini juga menemukan bahwa gambaran KMS yang paling banyak diharapkan adalah mengatur penyajian dokumen (dipilih oleh 64\% partisipan), disusul oleh memberikan point yang benar dan berbagi pengetahuan dengan orang lain di dalam komunitas (62\% partisipan). Tabel 4. menunjukkan gambaran Knowledge Management System (KMS) yang diharapkan oleh para siswa SMK.

Tabel 4.

Gambaran KMS yang Diharapkan Siswa SMK

\section{n KMS yang diharapkan oleh Siswa SMK}

KMS_1 : Memberikan Poin yang benar

KMS_2 : Memberikan Konten yang menyeluruh

KMS_3: Memberikan konten yang logis

KMS_4 : Konten mudah dibaca

KMS_5 : Konten mudah dipraktekkan

KMS_6 : Klasifikasi keahlian jelas dan mudah dimengerti

KMS_7 : Klasifikasi keahlian sesuai dengan pemikiran

KMS_8 : Pengelompokkan keahlian jelas dan mudah dimengerti

KMS_9 : Pengelompokan keahlian sesuai dengan pemikiran siswa

KMS_10: Mencari dan mendapat dokumen terkait jurusan

KMS_11: Membuat dokumen terkait jurusan

KMS_12: Mengunggah dan mengunduh dokumen

KMS_13 : Memindahkan dokumen terkait jurusan

KMS_14 : Mengatur dokumen terkait jurusan

KMS_15: Mengatur penyajian dokumen

KMS_16: Menentukan dokumen pengetahuan yang disukai

KMS_17: Merekam riwayat materi yang telah dicari dan dibaca

KMS_18: Memfasilitasi diskusi dengan orang lain di dalam komunitas jurusan ntase Rata- Rata Siswa

Setuju
62

58

59.8

56.6

49.8

48.6

57.6

49.8

53.8

58.2

57.2

58.2

53.8

64.8

60.4

55.4

54.4 
KMS_19: Membantu penyampaian saran dan umpan balik

KMS_20: Berbagi pengetahuan dengan orang lain dalam komunitas

KMS_21: Mengakses materi yang dibagikan di dalam komunitas jurusan saya

KMS_22: Seandainya saya dapat mengakses Sistem Manajemen Pengetahuan, saya akan menggunakannya

KMS_23: Jika saja saya dapat mengakses Sistem Manajemen Pengetahuan, saya prediksikan saya akan menggunakannya
60

62

61

56.4

Berdasarkan uraian di atas $100 \%$ siswa setuju dengan adanya KMS dalam sistem pembelajaran. Selain itu juga, lebih dari 49\% siswa setuju dengan gambaran KMS yang telah diajukan oleh peneliti. Ekspektasi siswa terhadap KMS adalah menghimpun berbagai informasi dan terutama mencakup pengaturan penyajian dokumen, memberikan poin yang benar, berbagi pengetahuan dengan orang lain dalam komunitas. Hasil penelitian ini memperkaya pengetahuan mengenai ekspektasi terhadap KMS yang diimplementasikan dalam pendidikan menengah. Penelitian oleh Chu et al. (2011) menemukan bahwa KMS dapat meningkatkan pembelajaran namun membutuhkan dukungan dari beberapa dimensi seperti orang, budaya, teknologi informasi dan manajemen. Hasil penelitian ini dapat mendukung hasil penelitian yang telah dilakukan oleh Abubakar et. al. 2017 yang menyatakan pembelajaran organisasi melalui KMS akan positif mempengaruhi proses penciptaan pengetahuan pada suatu organisasi.

\section{KESIMPULAN DAN SARAN}

Hasil penelitian menunjukkan bahwa $100 \%$ siswa menyatakan bahwa Knowledge Management System (KMS) diperlukan dalam sistem pembelajaran mereka. Sebagian besar siswa 64\% memerlukan KMS yang mampu mengatur dokumen dengan baik, 63\% memerlukan KMS yang mencakup seluruh pengetahuan, baik yang terkait maupun yang tidak terkait dengan bidang keahlian mereka. Selain itu, 62\% siswa menyatakan bahwa KMS perlu memberikan poin yang benar, dan memberi kesempatan berbagi dengan orang lain di dalam komunitas. Hasil penelitian ini dapat menjadi informasi yang berharga bagi pengembangan Knowledge Management System (KMS) di SMK di Indonesia.

\section{Ucapan Terima Kasih (Acknowledgement)}

Penelitian ini merupakan penelitian 3 tahun yang didukung oleh Direktorat Riset dan Pengabdian kepada Masyarakat Kementerian Ristekdikti; dan Lembaga Penelitian dan Pengabdian kepada Masyarakat Universitas Tarumanagara. Peneliti mengucapkan terima kasih kepada Kepala Sekolah yang telah memberikan izin melakukan penelitian lapangan, juga kepada para guru dan siswa yang telah berpartisipasi dalam penelitian ini. Peneliti juga menyampaikan terima kasih kepada para asisten peneliti: Claudia Fiscarina, Hartinah Dinata, Vivien H. Wangi, Desella, Alivia, dan Linda Sari yang telah membantu dalam proses pengambilan data lapangan.

\section{REFERENSI}

Abubakar, A. M., Elrehail, H., Alatailat, M. A., \& Elçi, A. (2017). Knowledge management, decision-making style and organizational performance. Journal of Innovation \& Knowledge, 4(2), 104-114. doi:10.1016/j.jik.2017.07.003 
Badan Pusat Statistik (2019). Jumlah sekolah, guru, dan murid sekolah menengah kejuruan (smk) di bawah kementerian pendidikan dan kebudayaan menurut provinsi tahun ajaran 2019/2020. http://publikasi.data.kemdikbud.go.id/ uploadDir/isi_02552295-057B4347-BCB3-71A2D1E2AEEC_.pdf

Chu, K., Wang, M., \& Yuen, A. (2011). Implementing knowledge management in school environment: teachers' perception. Knowledge Management and E-Learning. 3(2), 139152.

Daňa, J., Caputo, F., \& Ráček, J. (2020). Complex network analysis for knowledge management and organizational intelligence. Journal of the Knowledge Economy, 11(2), 405-424.

Harb, Y., \& Abu-Shanab, E. (2020). A descriptive framework for the field of knowledge management. Knowledge and Information Systems, 62(12), 4481-4508. doi:10.1007/s10115-020-01492-X

Misbah, Z., Gulikers, J., Dharma, S., \& Mulder, M. (2020). Evaluating competence-based vocational education in Indonesia, Journal of Vocational Education \& Training, 72(4), 488-515, doi: 10.1080/13636820.2019.1635634

Natek, S., \& Zwilling, M. (2014). Student data mining solution-knowledge management system related to higher education institutions. Journal of Expert Systems with Applications, 41(14), 6400-6407. doi: 10.1016/j.eswa.2014.04.024

Nonaka, I. (1994). A dynamic theory of organizational knowledge creation. Organization Science, 5(1), 14-37.

Nonaka, I., Totama, R., \& Nagata, A. (2000). A firm as a knowledge-creating entity: a new perspective on the theory of firm. Industrial and Corporate Change, 9(1) 1-20.

Ministry of Education The People's Republic of China. (2019). Statistical report on China's vocational education in 2018. http://en.moe.gov.cn/documents/reports/ 201906/t20190605_384566.html

Undang-Undang Sistem Pendidikan Nasional Nomor 20 Tahun 2003. (Indonesia).

Ramjeawon, P. V., \& Rowley, J. (2017). Knowledge management in higher education institutions: enablers and barriers in Mauritius. The Learning Organization. 24. doi:10.1108/TLO-032017-0030 